\title{
To the prospects of adapting seafarers of different nationalities as non-native speakers to the unified process of learning Maritime English through Unified English Language Communication Platform
}

\author{
N. A. Ivasiuk \\ National University “Odessa Maritime Academy” Odessa, Ukraine \\ Corresponding author. E-mail: nadin.ivasyuk@gmail.com
}

Paper received 01.09.19; Revised 08.09.19; Accepted for publication 12.09.19.

\author{
https://doi.org/10.31174/SEND-Ph2019-204VII60-07
}

\begin{abstract}
The research of the article is armed at substantiating common methodological aspects of on-line and off-line teaching Maritime English to seafarers all over the world. These aspects concern linguistic, neurolinguistics and psychological characteristics of the trainees - mon- native speakers who may study ME through IT ME Unified Communication Platform for seafarers or in the class room with virtual or real present trainer which over lapping. The article contains working hypothesis as for linguistic modelling of ME teaching process to the students, non- native speakers. This hypothesis is based on other scientists' researches and experimental teaching activity of the author in Shanghai University, Marine College. The intermediate results of the investigation demonstrated passible positive efficiency of the applied methodology in quantitative relation, further research will concern qualitative analysis.

Keywords: Maritime English, non-native speakers, on-line, off-line, linguistic modelling.
\end{abstract}

Introduction. Our investigation generally is devoted to creating IT communication platform as Unified communication service for teaching-learning subject-based professional terminology in maritime business: navigation, engineering, management in two modes: synchronous and asynchronous. [1, P.1] as we expect, cloud-based unified technology will provide open-source project with self-supporting and interactive, integrated learning environment [1, P.2].

In order to solve this complicated universal task it is necessary to interlink many aspects: pedagogical, linguistic, psychological, technological, etc. This article is dedicated to the problems of combining linguistic, neurolinguistics, psychological with pedagogical approaches in teaching non-native speakers, seafarers to Maritime English (ME) through IT communication platform, first of all "on-line" mode. Learning foreign/ English language (EL) for general and specific purposes in on line mode is provided by thousands of courses on 10 and more unlimited top platforms. The possibilities in using different devices for computer- mediated communication with real or virtual teacher are enormous. English language platforms for seafarers already exist: Marlins Test Platform, SeaTalk, MARTEL Plus, MARTEL - Maritime Tests of English Language, Captains - Maritime Training. They are based on mainly non-translational methods and cover the professional terminology of all shipboard qualifications and competences. These programmes in our estimate, are aimed mostly at intermediate and advanced levels for acquiring seafarers competence in subject based knowledge in English language. By the results of our questionnaire as for self-estimating theirs EL knowledge and skills, $70 \%$ of seafarers evaluated their level as average, closer to pre-intermediate level.

Our idea is to create universal EL communication platform, based on cloud technologies, for seafarers all over the world targeted at non- native speakers, levels A1/A2, reaching B1/B2. This Unified communication solution coming from the IT Platform (i.e public cloud) will provide:

- comprehensive presence. Users can see "always-on" "contextual presence" infor mation from the unified communication administrator;

- comprehensive connectivity voice, video and conferencing capabilities:

- native support for mobile devices;
- regular update;

- comprehensive functionality;

- cost possible avoidance [2, P.3]

In order to be successful in fulfilling these tasks and achieving positive results of teaching-learning process we should provide high reliability, exposure, access, efficiency in perceiving, encoding, manipulation, storage and retrieval of foreign/ English language information in the link "trainertrainee" How to achieve this - our scientific assumption - in close interconnection with linguistic modelling systems: informatology, imageability, sensitivity/sensology, communicative networks [3, P.97].

Many scientists devoted their works to the analysis of these systems in applied linguistics [4,5,6.7.8]

At the same time adherents of theory of content-based blended learning analyze its architecture stressing on many overlapping segments with those of the applied linguistics, such as cognitive retention of auditory and virtual material and the related changes of participants activity and their motivation [9. P.1]

The objective of our research is to trace and substantiate some aspects of linguistic modelling in connection neurolinguistics comprehension of foreign language/English language reality as frameworking of one side of blended teaching in on-line decision.

The subject of the research is to elaborate the model of metacognitive skills of future navigators in Maritime terminology on the basis of the operational chart of their professional activity with the perspectives of their life-long professional education development. As for the tools in solving the tasks of pedagogical approach and strategy of "trainertrainee" interaction on-line (or a classroom) it seems us appropriate to choose scaffolding with various levels of support. Besides levels of support which are reflection of the pedagogical approach we've referred to the forms of support:

- general support ("needs" and "musts");

- content support ("learning strategies");

- linguistic support ("building regarding the foreign language").

Linguistic support assumes prior activity like linguistic modelling of the teaching process of content-based education, in our case for future navigators. Having experience in 
teaching ME for students in Maritime Academy and summarizing our practical experience (and practical experience of our colleagues in teaching ME ) for navigators in our parent academy we've made the attempt to finalize the linguistic modelling of our teaching process for non-native speakers. As Unified EL Communication Platform is going to be aimed at reaching the gap between levels A 1/A2 and B1/B2 and should be convenient tool for learning ME by low-ability and medium-ability learners, non- native speakers who may have some certain difficulties in perceiving, recognition behavior and response execution the following levels of support are appreciated as necessary for achieving positive results in teaching-learning:

- The teacher in classroom/ Trainer in virtual laboratory gives support to individual learners;

- The learners in classroom support each other through pair or group work;

- The learning activities should be differentiated (in classroom and to some extent in virtual lab) for more or less able learners;

- The content learned in English supports content learned in Mother language;

- The content itself supports the learning through Mother language;

- The format of task supports the learning of content in both Mother and English languages;

- The tasks are supported with visual and auditory effects

The general scheme/model of Unified El Commination platform for seafarers is as follows:

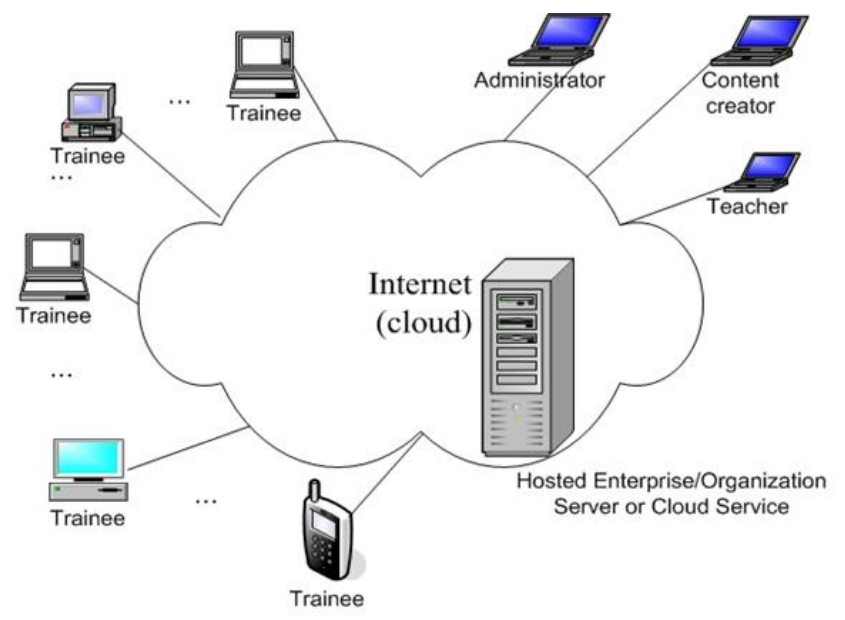

Fig. 1

The instructor/trainer who provides teaching ME on-line may have location in the native country and provide trainees' support in their native language. The approach and strategy of this support may be absolutely different depending on their origin: European, Asian, Midasian, African. There should be taken into account national and individual trainees' differences in word recognition behavior, their stability degree of pronunciation [10, P.5] accuracy of production of phonological (for word naming) or semantic (for lexical decision) which be taken to reflect response times in their behavioural lexical processing [10, P.6]

Every teacher-trainer interacting with his trainee/s decides/during his preparatory activity) how to indicate the greater efficiency of access, more salient representation of the lexical item (or definite portions of the whole thematic corpus) and greater availability of the representation within the individual learner's vocabulary [6, P.3]. This task can be solved, in our opinion, by creating favourable learning environment with positive impact on psychological factors affecting word presentation. Word frequency effect, word embedding word exposure in the whole teaching thematic model should be supported by auditory accuracy of phonological (for word naming) or semantic (for lexical decision) representation to reflect response times in behavioural lexical processing from the previous model experience to the present [6, P.6]. Local trainers should generalize sub-lexical routes they follow with the trainess. These routes map letters to sounds via a set of grapheme- phoneme correspondence rules and lead to lexical route containing word units. It can directly activate the phonology corresponding to the whole words. So we come to the one of the most important components of linguistic modelling- imageability in close connection with sensology -sensitivity.

Phonological framework of the word image depends on the neutralization/ mitigation of national accent differences to the benefit of ME proficiency on the standardization basis. Local trainer on line or in the classroom should take it into account. The trainee may feel inadequacy because of different number of phonems in his language and EL, different phonemic oppositions which to be established, each phoneme may have phonological restrictions, a number of vowels may occupy restricted articulatory and perceptual space in comparison [2, P.93-94]. These realizational differences may or may not have direct impact on the phoneme system neutralization of otherwise consistent contrasts [13, P.100]

For example, teaching English to Chinese speakers, the trainer should take into account 4 linguistic differences of English and Chinese:

- speaking rhythm;

- word stress;

- pronunciation;

- grammar [14, P.3]

Distinct pronunciation of all phonemes in English is not necessary if they are in an unstressed syllable. In comparison with Chinese language which is monosyllabic. Tonal shape for them should be changed and we consider it will be useful to train stressed time nature of EL through model words and word collocations. Our teaching material of ME lecture course for Shanghai Maritime College students concerned SOLAS, Survival technique, life- boat and fire-fighting drills. Cognitive tasks were connected with the following: - I - consonant - vowel - consonant - letters matching, stressing on correct pronunciation, rhythmic training.

- II -lexical decision with frequency effect word recognition, activation patterns with avoiding contextual ambiguities.

- III - semantic categorization with perceptual identification. If high frequency word patterns and facilatory effect of high neighborhood density of semantic coverage.

- IV - memory scanning with auditory and visual support of the material.

These tasks were interrelated with linguistic modelling tasks and principles. The fist tasks were performed by us by syllabification of the target words introduced, timing stressed syllables and not messing up the word-stress patterns. At the same time we should mind that Asian students have physical difficulties to pronounce the sounds [1] and [r], [v] and [w], [th], consonant clusters [tr],[dr],[st],[pl]. 


\begin{tabular}{|c|c|c|}
\hline $\begin{array}{l}\text { Subjective frequency us- } \\
\text { age }\end{array}$ & $\begin{array}{l}\text { Verbal-predicate } \\
\text { neighbourhood }\end{array}$ & $\begin{array}{l}\text { Objective } \\
\text { density }\end{array}$ \\
\hline Percentage-80-90\% & $90 \%$ & $60 \%$ \\
\hline $\begin{array}{l}\text { International maritime } \\
\text { treaty }\end{array}$ & to comply with & standards \\
\hline \multirow{4}{*}{$\begin{array}{l}\text { First and successive- } \\
\text { versions }\end{array}$} & to come into & force \\
\hline & to enter into & force \\
\hline & to pass & \\
\hline & to improve & $\begin{array}{l}\text { ship-to store } \\
\text { communication }\end{array}$ \\
\hline \multirow[t]{2}{*}{ Contracting state, party } & to update & \\
\hline & to amend & $\begin{array}{l}\text { in successive } \\
\text { forms }\end{array}$ \\
\hline verification & to adapt & \\
\hline successive obligations & to ensure & $\begin{array}{l}\text { in terms of gross } \\
\text { tonnage }\end{array}$ \\
\hline provisions & to add & new chapters \\
\hline \multicolumn{3}{|l|}{ construction } \\
\hline \multicolumn{3}{|l|}{ equipment } \\
\hline operation & to submerge & after damage \\
\hline extinction of fire & & $\begin{array}{l}\text { in the space of } \\
\text { origin }\end{array}$ \\
\hline restricted use & & $\begin{array}{l}\text { of combustible } \\
\text { materials }\end{array}$ \\
\hline \multirow[t]{2}{*}{ separation of } & & $\begin{array}{l}\text { accommodation } \\
\text { spaces }\end{array}$ \\
\hline & to minimize & $\begin{array}{l}\text { the rink of loss } \\
\text { of the ship }\end{array}$ \\
\hline \multicolumn{3}{|l|}{ proper maintenance } \\
\hline & $\begin{array}{l}\text { to apply or to re- } \\
\text { move }\end{array}$ & from the ship \\
\hline & to return to & $\begin{array}{l}\text { original state/up- } \\
\text { right state }\end{array}$ \\
\hline \multicolumn{3}{|l|}{ safety standards } \\
\hline \multicolumn{3}{|l|}{ ship design } \\
\hline \multicolumn{3}{|l|}{ safe operation of ships } \\
\hline \multicolumn{3}{|l|}{ ship types survey } \\
\hline stability & to meet & the requirements \\
\hline subdivision of ships & & $\begin{array}{l}\text { into watertight } \\
\text { compartments } \\
\text { vertical zones }\end{array}$ \\
\hline special measures & to enhance & $\begin{array}{l}\text { maritime secu- } \\
\text { rity }\end{array}$ \\
\hline requirements & to replace & $\begin{array}{l}\text { for life-boats, } \\
\text { rescue boats } \\
\text {.life-jackets }\end{array}$ \\
\hline \multicolumn{3}{|l|}{ damaged stability } \\
\hline \multirow[t]{3}{*}{ compartment flooding } & to conform to & $\begin{array}{l}\text { the Code of } \\
\text { Safety }\end{array}$ \\
\hline & & $\begin{array}{l}\text { for Mechant nu- } \\
\text { clear ships }\end{array}$ \\
\hline & to be safe & $\begin{array}{l}\text { and environmen- } \\
\text { tall friendly }\end{array}$ \\
\hline
\end{tabular}

Table 1.

Teaching techniques for pronunciation were the following. Auditory and visual presentation of the thematic target words, word mapping in cards with repetitiveness by individual students or in team after the trainer.

Training speaking rhythm in 4-beat sequences: clapping, clicking, movement, musical accompaniment

Lexical decision can be implemented by slide presentation of the target words with facilitating contextual explanation of their meaning in EL, translation into native language, isolated demonstration of them on the slide with hiding the whole context, then in the context, distinguishing these target words by "blinking effect". We hope it switch on memory scanning. The enforcement in memory scanning can be realized by "iconicity effect" - visual photo-images of the target words which will help to avoid contextual ambiguities. From lexical decision it is easier to come to semantic mapping and as a consequence trainees extended exposure to the vocabulary. If we present the teaching material in ME like SOLAS we should provide the accuracy of its model's semantic production. [15, P.12]

Semantic categorization is based on the thematic corpus which arranged in word clusters, collocations, steady expressions - subject-predicate-object - extending thematic comprehension through better decoding and higher order thinking process.

Introducing the first part of the presentation "SOLAS" we'd like to provide as high-speed of word decoding as possible, broad vocabulary knowledge and to establish fast word-to-text integration through the frequency semantic chart/map of the topic.

This semantic mapping was then contextualized and supported by all the demonstration effects described before, by video scenarios where "kinesthetic effects" were accompanied by trainer's explanation, working movements, gestures. It is especially vitally important if the $1^{\text {st }}$ language (native) translation is not possible.

Results and discussion. The experiment of construeing the framework of linguistic modelling the ME teaching process for nonnative speakers lasted during two academic weeks. During that time we implemented the methodics and measures described in the article. The start-up was as ascertaining experiment accompanied by supervision, interviewing trainees, conducting an initial test like knowledge slice. The developing experiment was pre- finalized by intermediate test and the test score was differentiating/ rising in between initial and intermediate by $15 \%$. As for results of our teaching process efficiency, we are going to continue the scientific research to the topic which by our analysis is not being detailed thoroughly yet.

Condusion. In this article we've tried to investigate one aspect of methodology working in Unified EL Communication Platform for Seafarers. It is very difficult to create linguistic modelling framework of teaching process on-line and off-line taking into account its linguistic, neurolinguistics, psychological aspects, other words generalizing ME teaching process for seafarers all over the word. It will become possible in our opinion, when combining cognitive process of teaching with detailed investigation and implementation of national phonological, lexical, semantic grammar layers of processing and self-processing from the $1^{\text {st }}$ language (native) to the $2^{\text {nd }}$ (in our case $\mathrm{ME}$ ).

\section{REFERENCES}

1. Ivasiuk N.A., Shapo V.F. Unified EL Communication as Service for Seafarers II "The New Wave of Excelleme in Maritime Education and Training" First Joint IMLA- IMEC- ICERS Conference Manila, Phillipines, 2018, P..1-9

2. Online sourc: https://www.cisco.com/clen/us/products/collat-

eral/unified-communications/unified-communications-manager-callmanager/write.paper.c//-604516.html

3. Ейгер Г. В. Лингвистика в аспектах хронотроники./Дискурсология.Вісник ХНУ № 897,2010, С.97

Eyher H.V. Linhvistyka v aspektakh khronotroniki. / Diskurcolohiya.Visnik KHNU № 897,2010, C.97 
4. Bradlow, A. R. \& Pisoni, D.B. (1999). Recognition of spoken words by native and non- native listeners: Talker-, listener-, and item-related factors. Journal of the Acoustic Society of America, 106, 2074-2085.

5. Canseco-Gonzales, E., Brick, C., Fischer, K., \& Wagner, K. (2005). 'Carpet or Carcel' effects of speaker type, fluency, and language mode on bilingual lexical access [Abstract]. Proceeding of the International Symposium on Bilingualism, Spain, 5, 156-157.

6. Chen, H-C., \& Leung, Y-S. (1989). Patterns of lexical processing in a nonnative language. Journal of Experimental Psychology: Learning, Memory and Cognition, 12, 397-401.

7. Cutler, A., Weber, A., \& Otake, T. (2006). Asymmetric mapping from phonetic to lexical representations in second-language listening. Journal of Phonetics, 34, 269-284.

8. De Groot, A. M. B. (1992). Determination of word translation. Journal of Experimental Psychology: Learning, Memory and Cognition, 18, 1001-1018.

9. Lewellen M.I. Yoldinger I.D., Pisoni D.B., Greene B.Y Lexical Familiarity and Processing Efficiency // J.Exp Psychol.Yen.Author Manuscript; available in PMC Dec.5, P.1
10. Monagham P. Chang Ya-Ning, Welbourne S, Brysbaert M. Exploring the relations between word frequency, language exposure, and bilingualism in a computational model of reading. //https: doi.org/10.1016/j.jml.2016.08.003 P.3.

11. Monagham P. Chang Ya-Ning, Welbourne S, Brysbaert M. Exploring the relations between word frequency, language exposure, and bilingualism in a computational model of reading. //https: doi.org/10.1016/j.jml.2016.08.003 P.6.

12. McMahon A. An Introduction to English Phonology Edinburgh University Press, 2012. // staffnew.uny.ac.id P.93-94.

13. McMahon A. An Introduction to English Phonology Edinburgh University Press, 2012. // staffnew.uny.ac.id P.100.

14. Ruthwickham. Teaching English to Chinese Speakers: 9 Major Differences to Be Aware of. // https:// www. fluentu. $\mathrm{com} / \mathrm{blog} /$ educatior -english/teaching-english-to-chinese-speakers/ P.4,7.

15. Solomon R.L., Howes D.H. Word Frequency, Personal Values, and Visual Duration Thresholds // Psychological Review,58 doi: 10.1037/h 0058228 P.257. 